\title{
Sublimity \& the Image: A Hermeneutic Phenomenological Exploration
}

\author{
Erika Goble, PhD candidate, Department of Secondary Education, \\ University of Alberta \\ Email: egoble@ualberta.ca
}

\begin{abstract}
For over 2000 years, the sublime has been a source of fascination for philosophers, artists, and even the general public at times. We have written hundreds of treatises on the subject, put forth innumerable definitions and explanations, and even tried to reproduce it in art and literature. But, despite our efforts, our understanding of the sublime remains elusive. In this paper, the sublime is explored as a potential human experience that can be evoked by an image. Drawing upon concrete experiences, the phenomenon of sublimity suggests a compelling, embodied response to the visual object that can evoke a fundamental change of being.
\end{abstract}

\section{The Sublime amongst Us}

We live in a world of images; some hold a powerful sway. Who among us cannot recall the force of the images broadcast on September 11, 2001: the Twin Towers-the falling man - the exact moment when having rushed to the screen we watched in horror and astonishment? ${ }^{1}$ That moment, when many of us stood in stunned amazement, struck dumb, seeing that which we never could have imagined? Images such as these can have a deep bite (Sontag, 2003): they can stay with us; haunt us, even as we might resist what we see. These are images with a piercing quality — what Barthes (1981) calls punctumthe resonances of which can reverberate across the planes of our existence (Bachelard, 1964). Many of these images form part of our collective memory, icons of a particular moment in time or of a shared experience (Hariman \& Lucaites, 2003; Taylor, 2003). However, some images have a force that is solitary, private, and individual (Barthes, 1981; Brunius, 1970; Ingarden, 1985). While seemingly only a picture, a video, a painting, or a drawing among the thousands we see daily, this image is somehow infinitely more. It is sublime.

Sublime. Historically, the term was understood as the simultaneous experience of awe and terror (Burke, 1757/1958/ 2008; Schopenhauer 1819/1958) evoked by something that exceeds our cognition (Kant, 1793/2000/2007). Considered beauty's unruly counterpart, it was the evocation of, or that which evokes, an enthusiastic terror (Dennis as cited in Kirwan, 2005. Deemed the height of aesthetic experience (Reynolds, 1785/1996) and the "highest excellence" of artistic expression (Longinus, 1971), it was thought evidence of transcendence (Schelling, 1859/1989) and even that, which could enable us to glimpse the divine (Otto, 1958; Reynolds, 1785/1996).

In this sense, however, the term is now infrequently used and may even go unrecognized. Now, 'sublime' is more often used in a hyperbolic sense to denote the 
highly pleasant, ${ }^{2}$ much in the same way that 'awesome,' 'great,' and 'fantastic' are used to describe phenomena that fall well outside of those words' true meanings (e.g., when we say "that dinner was fantastic!"). But, unlike these words whose meaning we can still readily call to mind if pressed (as generating a sense of awe, being of high status, or having a fantasy quality), we may not so easily recall what the term 'sublime' might mean outside of colloquial speech.

In academic thought, what constitutes 'the sublime' has likewise changed over time. Initially considered a feature of rhetoric "produced by greatness of soul, imitation, or imagery" (Longinus, 1971, p. 88), the sublime was reconceived in the $17^{\text {th }}$ and $18^{\text {th }}$ centuries as a specific experience and an identifiable quality of things (Costelloe, 2012). Edmund Burke (1757/2008) thought it "the strongest emotion the mind is capable of feeling” (p. 39), while Kant (1793/2000/2007) argued that it was a supersensible faculty that was central in the acquisition of knowledge. He proposed that the sublime was the overpowering effect of encountering something that exceeds our comprehension and imagination and which, through our ability to overcome it, leads to the realization of certain Ideas of Reason. Both Burke and Kant argued the sublime involved attraction and repulsion, in contrast to the beautiful, which contained only attraction. And, while writing outside of the arena of art, they also both upheld John Milton's Paradise Lost as an ideal example of the sublime (Costelloe, 2012; Chignell \& Halteman, 2012). The German Idealists believed the sublime-particularly in art-joined the ideal and the real (Hegel, 1835/1975; Schelling, 1800/1978; Shaw, 2006). Well-established in academic and popular imagination, the sublime can to influence much of the art and literature of the Romantic period. Artists like Casper David Friedrich and J.M.W. Turner sought to paint the sublime (Gracyk, 2012), while writers like William Wordsworth (Potkay, 2012) and Herman Melville (Welten, 2011) attempted to evoke it in literature.

Interest in the sublime briefly waned during the first part of $20^{\text {th }}$ century, before reviving en force mid-century. With that revival, however, a significant shift took place. Whereas the concept had been considered in terms of transcendence and universality, it was now taken up as a matter of immanence and transformation (for example, see Derrida, 1987; Lacan, 1986/1992; Lyotard, 1979/1984). The sublime with its essential paradox (Goble, 2008/2012) was and remains an ideal postmodern subject. It has been explored in terms of that which is put into the place of the Thing (Lacan, 1986/1992), the presentation of the unpresentable (Lyotard 1979/1984) the unimaginable (Derrida, 1987; Žižek, 2002), and the “enigma of awareness” (Welten, 2011, p. 206). The sublime has even been described as the movement of unlimitation at the limits of what is (Nancy, 1993). In cultural studies and the fine arts, the sublime returned to being a theory-du-jour, a favourite challenge for postmodern artists (e.g., Marina Abramovic [1992/2010] and Barnett Newman [1948/2003]), and a catch-all construct for those wishing to name, explain, or invoke that which exceeds rational thought and explanation. Most recently, the sublime has begun to take on a new form-a 'negative aesthetics' - in response to the question of how we might account for the aesthetic dimension of terror and terrorism (Berleant, 2010).

Given the term's current manifestations, particularly its philosophically abstract nature, speaking of the sublime as something encountered in the world is now largely limited to discussions of Romanticism, as if the possibility of experiencing the sublime were historically situated. But, has that which we once understood as sublime 
disappeared with the fading of its name, lost and relegated to the annals of history? What of the human phenomenon that underlies, motivates, and from which originates our multitude of attempts to analyze, theorize, and represent the sublime? Has that too been lost? Or is it still capable of being encountered in the world, through things like images, if perhaps only rarely? What if it continues to exist, but we have merely forgotten-or never knew-its name?

I take up these questions inspired by the American philosopher Guy Sircello (1993) who observed of our ongoing attempts to define the sublime that:

Sublime discourse often is, in many respects, gibberish-even if in some cases splendid gibberish-as any language might be that tries to articulate the extraordinary and stupendous in the very throes of confronting it. And it probably does foil rationalism in more than one sense-as does so much else in the world. (p. 549)

If Sircello is right and the sublime, by its very nature, confounds rationalism and undermines any attempt to explain it, one recourse for understanding it lies in approaching the sublime as a possible human phenomenon. I undertook a hermeneutic phenomenological study of the sublime when it is evoked by an image, following the practices articulated by Max van Manen (1997). ${ }^{3}$ These include collecting and phenomenologically reflecting ${ }^{4}$ upon accounts given by persons who believe that they have experienced the sublime due to an image ${ }^{5}$ as well as artwork, literature, and other writing that are revelatory of the sublime as it is lived. My purpose has been to create a rich, evocative text that reveals the sublime as it appears in lived experience, that we might begin to grasp the essence of its meaning or its eidos (van Manen, 1997). As well as attempting to evoke an embodied understanding through the written text, I have sought to generate in the reader a similar understanding of the images discussed by visually reflecting their essential form. ${ }^{6}$ It is hoped that this work will lead to further discussion and exploration of the sublime as it is encountered in our world. I believe, as Sircello (1993) does, that such a phenomenological exploration is urgently needed, as it "will manifest what sublime experience at bottom has to tell us-if anything at all-either about the world or about ourselves” (p. 542).

\section{Seized by the Sight of the Image}

Consider Arina’s account. ${ }^{7}$ She tells how:

I am waiting in line to buy bus tickets. I happen to glance over my shoulder at the magazine rack and it is like BOOM! this image immediately grabs my attention. It takes me off guard. 


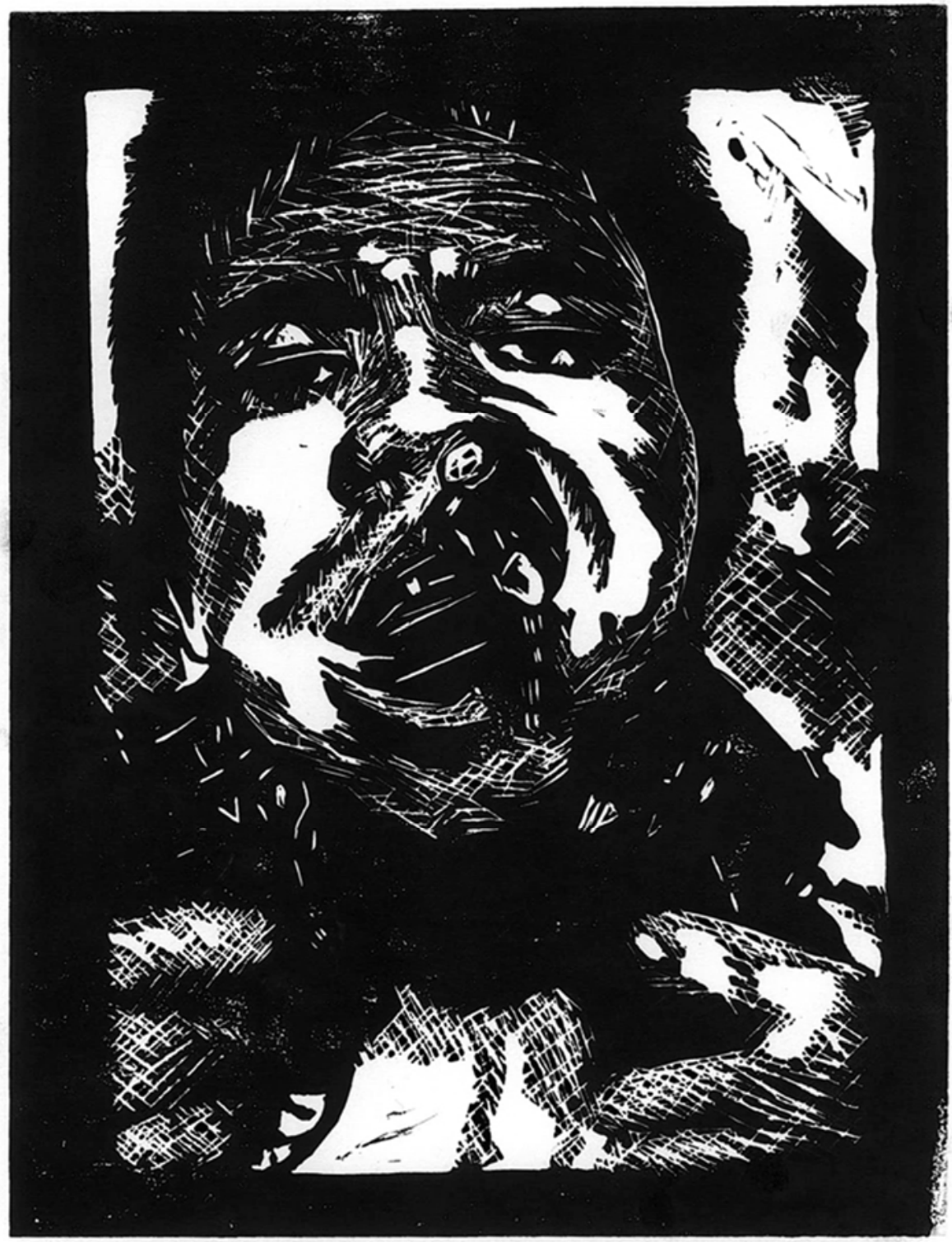

The picture is grotesque. But despite being so repulsive, it is also oddly compelling. I am somehow unexpectedly drawn to it. In fact, I can't take my eyes off of it. I just stare. Everything else falls away. It is like time and space stand still or have evaporated. There is just that image and me.

I am surprised at my own response. I keep wondering what is going on... Even though my body is moving in the opposite direction because I am slowly nudging up the line, my eyes remain stuck on the image. I can't look away.

As I slowly move further and further along the line, the space around me, what is actually going on-the line up, the people, the purchasesbecomes an annoyance because I don't have the time I want, the time I need... 
Like Arina's trek to the store, we largely move through the world unthinkingly, following our daily, weekly, monthly routines. But then, in the middle of the seemingly ordinarystanding in line to buy tickets-an image can suddenly grab us. We are seized by the sight of it.

But what about this image seizes and surprises? Not its mere presence, for we encounter images routinely and just as routinely we tend to overlook them with the same glance that we give the rest of our world. We might catch a glimpse of a pretty face looking out from a poster, or briefly stop to read a funny cartoon, or cringe away from the latest natural or manmade disaster, but rarely do we linger long before any of these. The attention we give to these images is of a secondary nature (Waldenfels, 2011). Our eyes briefly touch them, quickly taking in what information they offer up, then moving on. Even though we glance their way, we may remain preoccupied with whatever task is at hand, the movement towards which these images has only momentarily interrupted, sometimes not even involving a break in our stride, much less a suspension of our intentions.

When considered in this way, I wonder if we really see most images at all. They largely appear as we expect them to appear: as part of our daily landscape. We move in and among them habitually; so much are our reactions to them are determined by habiteven when we regard the most violent or destructive of representations - that, at best, they a form a visual white noise in our world.

However unlike the everyday image, which we briefly apprehend and just as easily release when encountered over the course of our day, when we encounter an image that appears sublime - a sublime image-it seems to reach out to us and, once it has taken hold, does not so easily let go. Arina finds that once she sees the photograph on the magazine cover she "cannot take her eyes off of it"-despite the fact she finds herself standing in line and must constantly move forward, ever further away from the image with each transaction of the till.

But, is she really experiencing the sublime? From her description, we might wonder if Arina is simply fascinated by the magazine's cover. She finds it compelling much like we can feel attracted by that which is fascinating. And yet more that it being compelling, the image seems to compel her eyes. It compels her, not as we are compelled to look at the beautiful, the noticeably ugly, or even the highly comic. Rather, the sublime seems to compel her towards that which, by all logic-including her understanding of herself-should be repellant. In its ability to compel us, a sublime image may "forcibly drive" our desire (compel, Online Etymological Dictionary, 2012) in a new direction towards that which we had never before considered or even thought possible, leaving us helpless before this movement of our soul.

In feeling so compelled, we might even say that her that Arina has become enchanted by the image. Enchantment is closely linked to fascination (fascination, $n$., Oxford English Dictionary, 2013) yet extends beyond it. In fascination, we are held and intrigued by a mystery that something presents to us. We look at an object from various angles, whether physically or metaphorically and perceive in it a secret that, with enough effort on our part, we will discern. Once that secret is revealed our fascination will wane. But this does not appear to be Arina's experience. While we can be certain that Arina's eyes explore the various details of the photograph, their movement is less directed 
towards some goal. In fact, she does not describe her look as doing anything. She just stare[s], momentarily moved to stop moving, to simply coexist with this image.

Stories of being enchanted describe how someone is put under a spell and moved to do things they would not normally do or to enter a state of timelessness. Arina does appear to be spellbound by this image. Placed under its spell, it seems to heighten her perception of the image to all else and suspends her sense of time and space. From this, we might suspect that Arina has entered a state of 'originary attention,' which according to Waldenfels (2011):

Allows us to savour a taste, dwell on a view, appreciates a thought and also a mood. Far from the habitual secondary attention which expects something that is not yet present, the originary attention waits for something which will never be fully there. It not only extends experience but also increases it. (p. 65)

Arina is not waiting, fascinated, for the photograph to reveal its mystery to her; she is dwelling with the image in a new and unique way. To be so effected by an image can be startling, particularly when its subject may be so ugly. In life, we largely turn away from the ugly, grotesque, and horrific. Our eyes mimic our social shunning. And yet, Arina is drawn to this image. Indeed, she is not able to look away from it even if she wanted to. When we encounter a sublime image, our gaze can become paralyzed by it

Edward Casey (2007) suggests that our glance routinely encounters the world as image and that the image is the 'proper object' of the glance. Yet when we encounter a sublime image the fleeting glance may immediately turn into a prolonged gaze. For JeanLuc Marion (2002), the change brought on by the gaze is one of 'admiration,' and it "is only fixed on what can stop it by its deployment of visibility” (p. 59). Perhaps the sublime that enchants is a form of visibility that stops our glance and transfixes our gaze. But if that is the case, then might our response be one of admiration, if in the extreme?

Arina finds the image both repulsive and attractive, and admits, "I am surprised at my own response. I keep wondering what is going on." The duality of her response is as unusual and surprising to her as it may be to us. Attraction and repulsion are normally considered opposites. They are formally defined as graded antonyms; concepts the meanings of which are opposite to one another and which exist along a spectrum (other examples include happy: sad, hot: cold, young: old). Yet, somehow, Arina is experiencing the two opposites simultaneously. The paradoxical coexistence of opposite responses has long been understood as a fundamental feature of the sublime, ${ }^{8}$ even as philosophers and theorists have argued how to best explain their simultaneous experience. For postmodern scholars, the 'irresolvable conflicts' found in the sublime are the essential and creative forces of the experience (Johnson, 2012). One merely accepts their coexistence.

According to H.W. Hepburn (1984), however, it is wonder that holds in 'tense equilibrium' the paradoxical emotions of the sublime, the "duality of dread and delight" (p. 151). Etymologically and phenomenologically, admiration relates to wonder (Hove, 2012; admiration, n., Online Etymological Dictionary, 2012; admiration, n., Oxford English Dictionary, 2013). Does an encounter with a sublime image then evoke a form of admiring wonder? While we readily admire many beautiful and serene things-we even 
call them wonderful - we may hesitate to say the same of a face mutilated by guns. It seems strange and wrong to admit to admiring or finding wonderful an image that can turn our stomach like a violated human face. To do so seems to ascribe to this grotesque and violent form a positive, pleasant quality that runs counter to its very nature. Is this not what Hepburn claims occurs in the instance of the sublime: wonder holding together the awful and the awe-full in some incomprehensible way? In an examination of wonder, B. Elliot Stone (2006) writes, "When experiencing something truly awesome, one cannot understand it, nor will one ever be able to understand it. This is what 'sublimity' means" (p. 210). We, like Arina, might be able to articulate the paradoxical aspects of our experience, we may be able to describe how we are both attracted and repulsed by an image, but the totality of our experience remains strangely beyond our understanding. For Elliot Stone, however, the awesome incomprehensibility of the sublime is not authentic wonder-merely something with which it may be confused.

While Elliot Stone offers a long philosophical analysis of the difference between true wonder and wonder as curiosity, to follow this route takes us away from the lived experience. Moreover, we can find in Arina's account an important distinction between wonder and that which is experienced with the sublime image. According to Hepburn (1984), wonder "rests in its objects, once they are judged in some way worthy of wonder" (p. 134). Herein lies an important difference between wonder and what drives Arina's response. Arina does not judge the image to be sublime. Rather, the image seems to immediately give itself as sublime without any effort on her part. Indeed, the sublime image stands forth in a sudden rush and demands her attention, her gaze, in such a way that her already unremarkable world becomes even less so. Arina does not look upon the image and determine it to be sublime, wondering and admiring it for that reason. She immediately encounters it as it appears: it is sublime. It is so present to her that everything else-even her sense of time and space - falls away. She can only stare. This type of change was noted by Edmund Burke (1757/2008), who wrote: "the passion caused by the great and sublime... when those causes operate most powerfully, is Astonishment; and astonishment is that state of the soul, in which all its motions are suspended, with some degree of horror” (p. 53).

Like Arina, a sublime image can so thoroughly grab our attention that we are enchanted and momentarily suspended by it. The achievement of our original reason for moving about our world (such as entering a store to buy tickets) can become secondary to the sudden demand to attend to the image before us. The etymological origins of the word 'grab' lie in ghrebh- and grabiti, meaning 'to seize, reach' in the sense of seizing a 'possession or prisoner' and 'to rob' (grab, Online Etymological Dictionary, 2012). Unlike other images that we possess briefly through our selective attention, the sublime image can seize us. It can possess us and, in doing so, can seemingly rob us of whatever purpose or intention that had previously occupied us. In this way, the experience of encountering a sublime image seems to involve a taking of our intentions. Indeed, we might say that the sublime can seemingly change our intentionality. But, if it is a taking away of what was at hand-or, rather, if the sublime image can cause us to turn away from our present way of being in the world - towards what does it newly orient us? 


\section{The Sublime Image: Quality or Experience?}

Given that I am exploring the experience of encountering sublime images, the first course of exploration must be of the image itself. Quite evidently, when we encounter an image and experience it as sublime we take notice of it in a way that we do not with other images. We attend to the sublime image differently. But what about the image makes it sublime? What causes our relationship with it to be so different from the norm? To what does it demand we attend? There has been a debate throughout the sublime's long history as to whether the sublime is as an intrinsic quality of select objects-like redness or roundness - or an experience induced by an encounter with an object. This is sometimes described as the difference between 'sublime style' and sublimity (Costelloe, 2012) and, until now, I have been deliberately vague in my use of language to avoid having to make an assertion either way.

Maurice Merleau-Ponty (1964) notes:

The evidence of the perceived thing lies in its concrete aspect, in the very texture of its qualities, and in the equivalence among all its sensible properties — which caused Cezanne to say that one should be able to paint even odors. (p. 6)

If this is the case, it is possible the sublime may be identifiable within the subject matter or the formal qualities of 'sublime images.'

Let us take as our example the Pulitzer Prize winning photograph taken by Kevin Carter. ${ }^{9}$ It is regularly listed amongst the most famous photographs of all time. The image, a beautifully haunting testimony to famine, has become iconic of human misery (Purcell, 2010). The photograph is flush with the yellows and browns of a drought-ridden land. It shows a young Sudanese child, starved and collapsed, behind whom sits a vulture apparently waiting for the child's imminent death. Even without knowing the context in which the photo was taken, the close proximity of the child to the vulture suggests the image is symbolic of life and death. And yet, the pairing of child and vulture does not seem to be where the possible sublimity of this image lies. Unlike many other images symbolizing the confrontation of life and death, this image does not show a balance between the two. Rather, the photograph appears poised at the moment right before death wins out over life. Although we normally think of children as our hope for the future, in this photograph the child holds no such promise. She is this promise thwarted. She is a child who cannot even hold herself upright. The weight of the struggle of her brief existence draws her body to ground-her head weighing down upon her starved limbs. There is no evidence of the vitality and vigor that we normally associate with children. Indeed, it is not hard to imagine this child dead. The vulture, its body tensed, watches and waits - much like the viewer, him- or herself. We wait in horrified anticipation of what we cannot doubt will happen. And yet this realization never comes about for this is a still photograph. The image is forever frozen in the anticipated moment of the child's deaththe sublime moment where life and death simultaneously co-exist and commingle. 


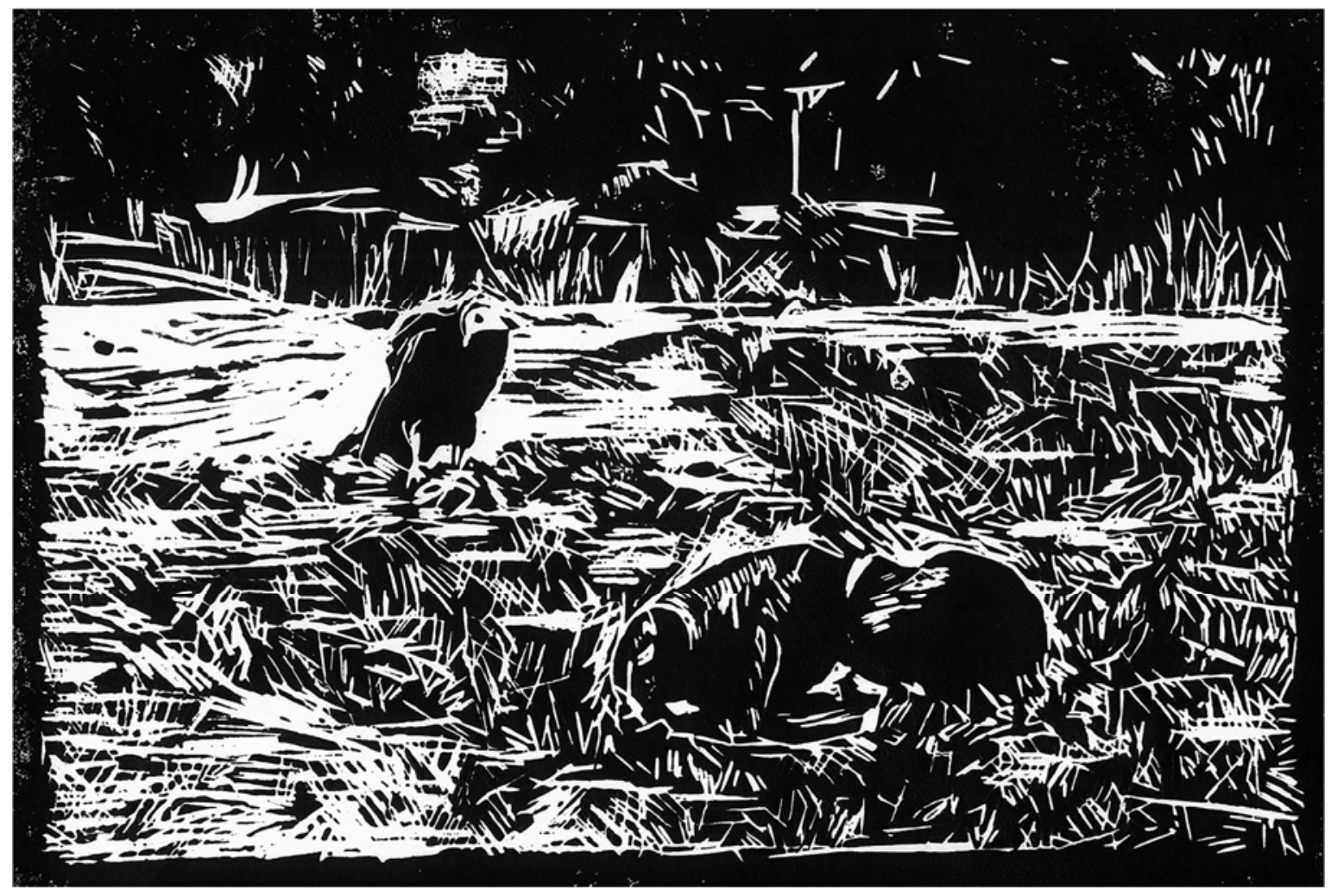

The power of Carter's image is so strong and readily apparent that the photograph is easily recognizable: most people are familiar with it. Although, few today can recall the exact situation that led to the child starving, or even the general context in which the image was taken. According to L. Sebastian Purcell (2010) the feelings this photograph routinely evokes among viewers "attests to the phenomenological warrant" (p. 16) to consider it in light of a revised phenomenology of the photograph. For Purcell, Carter's image is an exemplar of the 'amplitive' nature of certain photographs. He writes, the girl "introduces an affective and meaningful dimension to the photograph that qualitatively transforms it into a different kind [of] image” (p. 17). What Purcell's statement astutely captures is the fact that it is not the bird, but the child that makes all the difference in our experience of the image. The child is both life and death. It is in the very beauty and dreadfulness of the photograph's subject that may transform the photograph into something sublime.

Given its subject matter and its sublime amplitive affective qualities, neither the photograph's fame, nor the public response should surprise us. Indeed, we may be attracted to its poignant subject matter, compelled to look at it, and simultaneously feel an absolute, utter horror towards what we see-so much so, that our horror can even extend to the man behind the camera. From the moment the photograph was first published, Carter was vilified for having taken it. ${ }^{10}$ If we consider the sublime image in terms of Gaston Bachelard's (1964) notion of the poetic image, it appears that - whether as its creator or its viewer-an image's sublime subject can seemingly "take root" in us (Bachelard, 1964 p. xix). It can "becom[e] a new being in our language, expressing us by making us what it expresses; in other words, it is at once a becoming of expression, and a becoming of our being. Here expression creates being” (Bachelard, 1964, p. xix). While 
this may be uplifting when considered in light of poetry, it can be damning when conceived in terms of certain sublime images. Carter's photograph creates and permanently fixes the image of a hopeless, starving child. It creates and fixes Carter's complicity as the image's creator. It creates and fixes our own involvement and complicity as its viewers.

The world remembers Carter's photograph over a decade after it was taken. For a few, it simply represents the issue of international disasters and the need for ongoing foreign aid. For many others, however, it invokes the basic sublime paradox of human existence: misery amid beauty, and the constant coexistence of life and death. In this way, uniquely, beautifully, terrifyingly, the necessity of the existence of Carter's photograph can become our own necessity. We may take it up within ourselves and it can shape who we are and become. Mikel Dufrenne (1973) wrote, "the aesthetic object does not really belong to me unless I belong to it” (p. 404). When we encounter Carter's photograph, we may find that rather than our possessing it through the act of seeing, once its subject is seen it comes to possess us. We belong to it. Even when we may not want it, the deep rootedness that this image can take within us may be true none-the-less. And this may be no less true of the image's creator than of those who feel addressed by its sublime content.

I have used Carter's famous image deliberately, not only for its general recognisability but also because of the recognisability of a certain reading of its subject. As we consider this image, we may find understandable the claims that it contains a fundamental paradox in its subject matter and, further, that its terrible subject matter is beautifully and compellingly rendered. We may also find understandable how someone could experience the image as sublime. However, this is no guarantee that every person will experience this particular image as sublime. We must therefore pause before ascribing the potential sublimity of Carter's photograph (or any image) exclusively to its subject matter and formal qualities. No image can make such a promise. In this way, the sublime appears to differ fundamentally from other qualities, like 'redness' and 'roundness' that can be attributed to select objects. Although we should not discount the potential influence an image's subject and formal qualities can have upon the experience of the sublime, an image's sublimity does not appear to adhere solely within the objective thing. Indeed, we may be the only person to perceive the sublime in a particular image. The sublime, then, is to be not 'found in' select images, even though it may arise because of them. Somehow there is something more to our experience, for our response of sublimity - even when evoked amid a crowd — is often singular and unique.

\section{A Change in Seeing, A Change of Being: Facing Existence}

Our interest now necessarily turns to the question of the sublimity of images as a relational experience-one that arises between viewer and viewed. Given the centrality of sight to the phenomenon, might we understand sublimity in terms of how we literally see the image? Returning to Arina, we may find clues her turn of phrase "it takes me off guard." To guard comes from the Old French word garder, "to keep watch over, and protect” (guard, Online Etymological Dictionary, 2012). Before seeing an image that evokes the sublime, we are largely comfortable and safe in our world, protected by habit 
and routine. Little disrupts us. Indeed, we often actively avoid those things that cause discomfort. We are safely enmeshed in life-in some ways blind and ignorant-until we happen to glance over. And then, like the explosion Arina references, an image appears that drastically alters our world.

But what, really, has changed? Objectively: nothing. We can't point to something, like a person who has entered the room or a wall collapsing, and say, "that is the cause of this different world.” Nothing is out of the ordinary and yet everything appears to be. Our world seems the same but it is not, for we are not the same. As J.H. van den Berg (1972) writes, "That which touches us shows itself in the appearance of objects" (p. 80). The sublimity of the image has shattered our everyday attitude and it changes how we see and experience our world.

In the face of the sublime, our world may seem to stop. Even we may seem to stop. Yet, how might this movement towards 'suspension' be understood? The change for Arina occurs almost instantaneously, too quickly to articulate in any detail. But, consider Emma's account of walking into a gallery and seeing a large black and white canvas depicting farmers at work in a field. ${ }^{11}$

The piece is beautiful, ghostly. Almost like a whisper. At first, I think it must be made from charcoal, but it is unlike any charcoal drawing I have seen. It's not a drawing at all, more like a painting. I lean in to check the medium.

Ashes.

I step back as a hollow fills my chest and stomach. I stare at the picture, at the silent ghostly bodies, at the scorched earth. Ashes.

A hollow fills me, fills the space around me. It is echoed in the silence of the gallery. It becomes so consuming, so present that I feel it press in upon me, as if screaming in my ears. It is a realization that I cannot bear to voice. Ashes. 


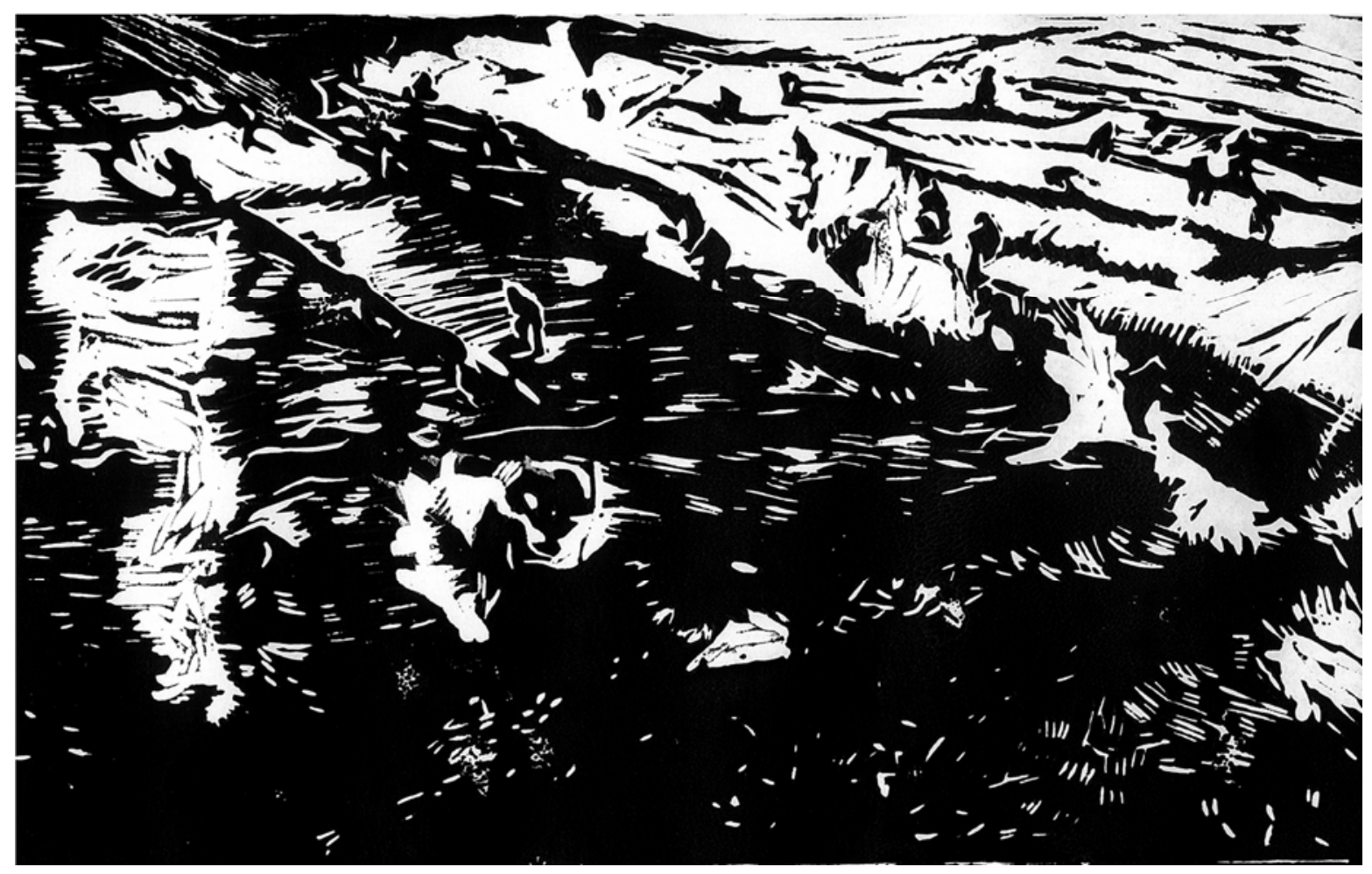

Unlike Arina's sudden transformation, Emma's comes upon hers slowly. In discovering the painting's medium, in the moment she recognizes it to be ash, the image changes and ignites a change in her.

Yet, what is the cause of this change? Why is Emma moved by discovering the painting to be made of ash as opposed to charcoal? Charcoal, as all school children know, is burnt wood. By all accounts, it is ash. And yet there seems to be a qualitative difference between the two. Charcoal is its own substance, especially when used as an artistic medium. Ashes are remnants of something else, even when spread upon a linen canvas. Therefore, Emma begins by looking at a charcoal drawing and she finds upon its transformation into ash that the presence before her becomes only an overwhelming absolute absence. She no longer sees a charcoal depiction or representation. What had first suggests itself as a whisper, something present though intangible, becomes apparent as a ghost, an ephemeral suggestion of what had once been which is now so long gone that it no longer even has physical form. It is a painting made of life no longer present; life that exists in ashes, a mere memory of the vitality and force it once held. As she looks upon the ashes, Emma finds herself gazing upon life destroyed—scorched — by the fact of its own existence.

Such a realization is surely an existential one; one to which Emma is not immune. And it is a realization bound to the phenomena of fire and ruin. Ruins occupy a special place in the human imagination (Harbison, 1991/ 2001), whether they be architectural (Harbison, 1991/2001) or of artworks (Jager, 2004). "Ruins are a way of seeing" (Harbison, 1991/2001, p. 99). It is a way of seeing that, when induced by art, can lead us out of our everyday attitude into what Bernd Jager (2004) describes as a festive world and where our being is called into question. The greatest creator of ruin is fire. In fire, we see something transformed from its complete, 'living' state to ruin. To watch the fire is to be 
witness to this transformation from one state of being to another. Gaston Bachelard (1961/2012) asserts, for that someone before a fire:

He thinks of life. He thinks of death. The flame is precarious and courageous. This light is destroyed by a breath, relit with a spark, easy birth and easy death...

But when one dreams more deeply, this lovely equilibrium of life and death in our thoughts is no more. In the candle dreamer's heart the word extinguish has such echoes! (pp. 16-7).

The ashes that Emma encounters-remnants of flame extinguished-seem to cause Emma to dream deeply and hear the echo of her own eventual extinguishment. She may even sense it doubly through both the painting's ashy surface and that which it depicts in its ghostly manner: farmers scything a field. It is death beautifully depicting death. According to Harbison (1991/2001), to respond existentially to ruin is only natural. He writes, "practically any human thing slipping into dereliction... engages our feelings about where we see ourselves in history, early or late, and (in poignant cases) our feelings about how the world will end" (p. 99). Ruins lead us to meditate on existence, to become aware of it.

To face the sublimity of an image may be to face existence. In previous work (Goble, 2008/2012), I have described this as a watershed moment of creative being, a moment when the sublimity of the artwork calls upon us to recognize our temporality, lowness, and insignificance even as this realization brings with it a sense of absolute freedom and creative potential. This freedom and creative possibility, while exhilarating, can be terrifying. As Italo Calvino (2009) observed, "what is terrifying and inconceivable is not the infinite void [of space] but existence" (p. 68). The sublimity of an image is the sublimity of a specific moment, and it may create an acute awareness of our present life, that we will surely die, and that our vital existence-no matter how precious-when extinguished will leave nothing behind but ash and silent ghosts.

We may physically feel the reverberation of this realization within the depths our body and all around us. It may fill us, fill the space around us, and refract back on us, press[ing] in... and screaming in [our] ears. We are free but finite beings-this is $a$ realization that we face but may not be able to bear to voice. In the sublimity of an image we may intuit the terrifying and inconceivable realization of our freedom, finitude and existence, a realization that can only be deeply personal and individual.

It would be tempting here to suggest that in bringing us face-to-face with existence, we encounter the nothingness of the void of existence and that our selves are threatened by it. And yet, this does not seem to be the case. While the sublimity of an image may question our being, we seem completely present to the questions it raises. They are our questions. Then, how might we understand the sense of hollowness of which Emma speaks if not as a loss of self? Emma describes a feeling of silence that is echoed and amplified by the silent gallery. Might it be that in the moment of seeing the sublime image, the meaningless chatter of our internal monologue is momentarily silenced? The image, having caught us by its whisper, turns silent and makes us silent. 
The silence may still our voice, fill our environment, and fill us, leaving us with only who we are-forcing us to face who we are-in the presence of the silent object before us.

\section{Revelation and Paradox}

As much as our experience of the sublime appears to be of our world, arising as it does from an encounter with an image, invariably the world will intrude upon us. Whether or not this intrusion is desired, at some point we will be forced to turn away from the image and return to the mundaneness that we had momentarily left. But, even as we first look away and then walk away from the image we may continue to feel the sublime's unceasing demand. While some may wish to keep the sublime image close through purchase of the original, acquisition of a reproduction, or simple memory, others may desire distance and wish they had never seen it. Kayla recounts one such incident:

I am sitting there and, at first, I don't really know what it is.

Kayla initially encounters this image as just another given image appearing within her taken-for-granted background world, one image among thousands. But, it is not quite like the others; something about this image gives her pause. The image shows itself to Kayla but it is not fully comprehensible. So, Kayla gives this image more consideration than usual.

Kayla's description of first seeing the image begs the question of whether it may be an inability to properly see the sublime image that holds our gaze. And yet with all images, there is always more to understand. Each can form an 'endless hermeneutic' (Marion, 2002) if we can approach it from a position of 'originary attention' (Waldenfels, 2011). How, then, does the sublime image differ? At first, Kayla sees the photograph, but does not grasp it. Indeed, there can be a fundamental confusion about the image before us in a sublime encounter. Facing the image, we may flounder "to catch hold of" something that seems to be given in our experience (comprehend, Online Etymological Dictionary, 2012) but which we do not fully comprehend. Again returning to Edward Casey (2007), perhaps it may be the failure of our glance to grasp the essential image that makes the sublime so powerful when we finally do.

Kayla tells of her moment of comprehension, the moment the image finally, completely gives itself to her:

When I finally realize what I am seeing, it is as if I have looked too long. 


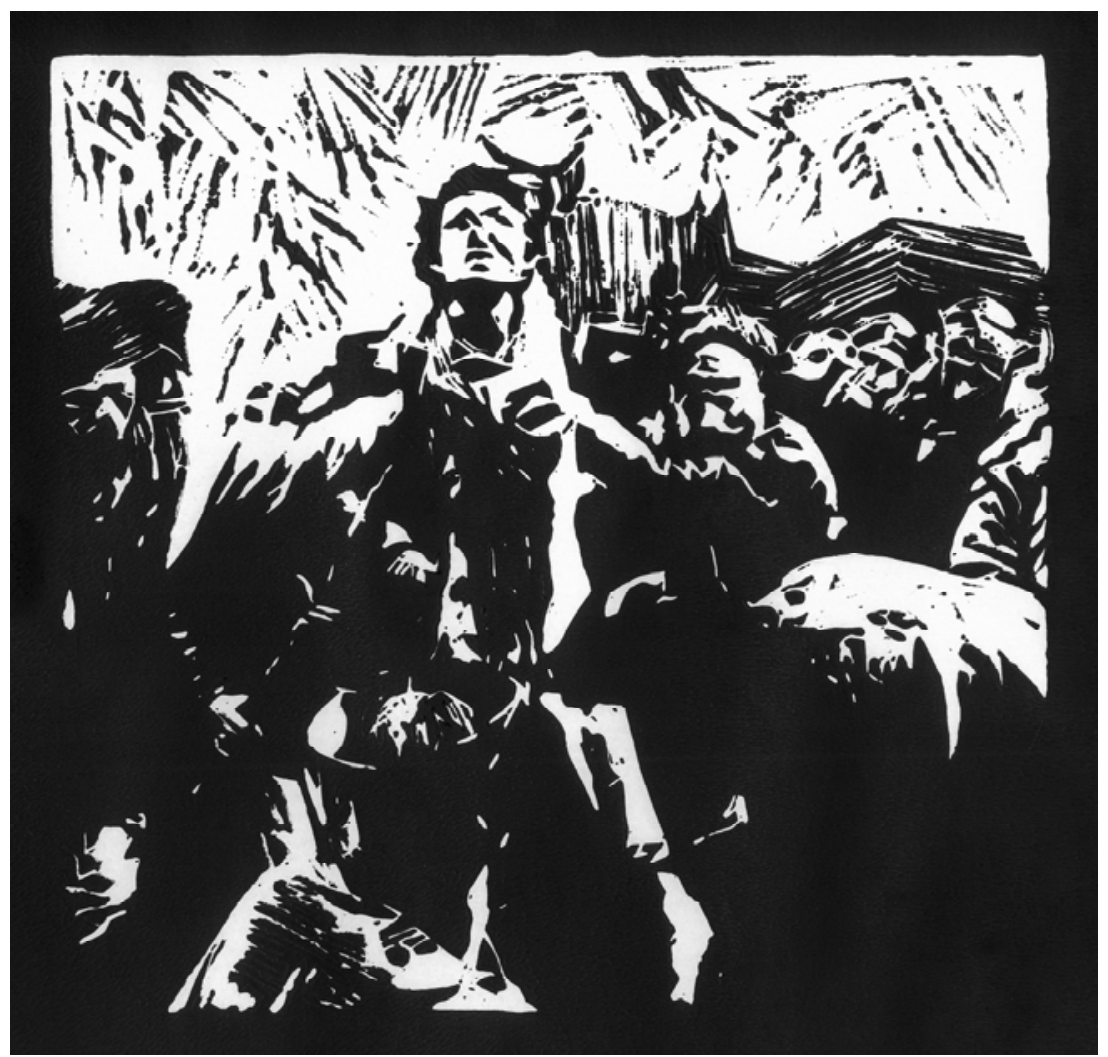

Kayla sees a woman standing amid a crowd of people as a group of men slowly remove the flesh from her body. It is one of the photographs of Lingchi, the infamous 'death by a thousand cuts.'

In the act of fully seeing an image-seeing it with knowing eyes and understanding - we, like Kayla, may feel we have seen something we should not have seen. Jean-Luc Marion (2002) writes, "the saturation of the visible becomes, to the one who knows how to look at it as it gives itself, really unbearable” (p. 67). To look when one knows how to see can be painful. In glimpsing the sublimity of an image, we may find it overwhelming, like the brilliant light that is the very root of the word glimpse (glimpse, Online Etymological Dictionary, 2012). Like Kayla, an image may reveal its sublime nature in the blinding light of understanding, leaving us raw and sensitive to our world, hurt by the very act of perception.

But what pains us? For Kayla:

To see such images is to feel the pain of the other. To be drawn to their suffering.

In seeing the image of Lingchi, Kayla is overwhelmed by the suffering of another to which she must respond. But, even as she responds, Kayla recognizes that the photograph is a "depiction, a representation of another's suffering," not the presence of suffering itself, and this is a dreadful realization. While the sublime image may be revelatory, when this knowledge is unpleasant or terrible, we may be forced to know without recourse. We become impotent, denied our innate desire to respond. To know is to “admit one's knowledge” (know, Oxford English Dictionary, 2013). In seeing an image of torture, 
famine, or death, we not only become acquainted with their brutal forms but may also be forced to admit our knowledge of and complicity with them through our shared humanity.

To endure the power of such images is, for Friedrich Schelling (1859/1989), an attestation of moral character in the face of one's nothingness. He writes, "Moral and intellectual flaccidity, weakness, and cowardice of disposition invariably shy away from these great [sublime] perspectives that hold up to them a terrible image of their own nothingness and contemptibility" (p. 87). And yet, such philosophical reassurance offers little solace. Facing such images, we may feel we are being asked too much, because 'to know' is also to "recognize [a person] in relation." (know, Oxford English Dictionary, 2013). In our moment of recognition, we are denied that fundamental relation that demands we alleviate the other's pain (Sobrino, 1992). To invoke Emmanual Levinas (2006), we may be called by the face of the other but cannot respond to its ethical demand. We witness the violence but cannot stand as witness to it. And this can torture us in turn (Leier, 2012). Kayla concludes: "It bothers me even now."

But, we should pause here, because it would be remiss to so easily accept this experience as sublime without further examination. We must ask ourselves: when we look at this photograph, do we see only torture and human debasement? Do we experience only the terror of our own impotence? If so, these images are not sublime but merely pure horror. Just as not everything that attracts us is sublime, neither is everything that repels. For the experience of a Lingchi photograph-of any image - to be considered as sublime, there must be something more to our experience than simple horror, terror, and repulsion. Perhaps, there is something else in this singular image-something that might be just as terrifying to encounter.

If we closely consider at how we look at this image, we might notice something about our looking that many of us might rather not see. As we gaze upon the terribly violent death that the image documents, we may find our eyes drawn upward to the face of its victim. In gazing upon her face, we may perceive in it her humanity. And, in her humanity, we may perceive something of the mystery of existence. Looking at the woman's countenance, despite-or perhaps because of - being at the moment of death, her face seems uplifted, almost joyous. ${ }^{12}$ Her visage appears to stand in absolute defiance to the violence being perpetrated upon her physical body. It is as if she has risen above the violence to which she is the closest witness. Her face reveals her sublime grace as a human being and attests to the fact that no matter what we might endure, something of us always remains beyond human touch and destruction.

Fifty years ago, Rudolph Otto (1958) connected the sublime to the numinous, that mysteriousness of existence, the awareness of which he argued underlies all religious belief. In looking at the woman's face do we not perceive in some strange way the mysteriousness of her existence? And our own? Might we not also perceive in her countenance that, of all of the millions of possibilities and all the things that could have gone wrong, it is miraculous that we came into existence? Is it not possible that, through her, we might see a trace of the numinous?

As difficult as such an admission may be for many of us to make, it may suggest what is uplifting and exalted within the admittedly terrible Lingchi photograph. The image seems to contain an impossible but fundamentally important transformation from horror to ecstasy and grace. We might even call it sublimation. In both realms where the 
term is used, psychoanalysis and the physical sciences, 'sublimation' involves an unusual change of states of being. In science, sublimation is the shift from solids to vapor without liquefaction (Oxford English Dictionary). In psychoanalytic theory, ${ }^{13}$ it involves the transformation of instinctive but unacceptable or impossible impulses into socially acceptable forms that may be entirely unrelated to the original (Shaw, 2007/2010). In a similarly unusual change of states, the photograph of Lingchi seemingly suggests a move from being an image of horror and debasement to one of exaltedness and grace. Indeed, one might even feel that they are witnessing transcendence.

Within the Lingchi photograph one sees evidence of both the worst of humanity, the worst of what people do to one another, and the most glorious, mystifying fact of human existence. But this realization can be difficult and, in some ways, this picture may be considered monstrous because it so eloquently, evidently, and explicitly shows us the simultaneity of two extreme opposites. This co-existing duality echoes Georges Bataille's (1949/2003) very claim about the origins of art and religion: they simultaneously contain horror and ecstasy, sacrifice and transcendence. Therefore, perhaps the common desire to abhor this photograph is not only because we are tormented by what it reveals to us of human beings. Perhaps we are also tormented by our acute awareness of this image's fundamental paradox.

Is the sublime, then, simply a paradox? The accounts we have explored thus far lend themselves to this suggestion. The Lingchi photograph reveals both extreme violence and divine grace. Emma encounters the painting both beautiful and unbearable. Carter's photograph merges life and death becoming both captivating and horrific. Arina is both repulsed and compelling. But, if it is a paradox, it is more than merely the paradox of response or subject matter, for is it not a paradox that the sublime, when encountered, is both there and not there? That I may see it most evidently in a given image while others do not? Is the sublime not somewhat like Marion's (2002) religious icon, the invisible made manifest, wherein I experience the sight of God looking back at me because I see him? Is the sublime then, perhaps, that which is most paradoxical and sublime of all: an encounter with the divine?

\section{Conversion}

We have entered contested ground. Philosophically, the sublime has been distanced from religion since Edmund Burke. However, the resonance between the sublime and divine has and continues to be felt philosophically (Herbert, 1998/2010; Morgan, 2009) and experientially. Chad tells of studying one night with a friend who shows him an art book. In it, he finds a reproduction of Caravaggio's Doubting Thomas. ${ }^{14}$

There was something with the painting I had never seen before. The story has always been incredibly meaningful for me, but Caravaggio made the story near, alive and different. 


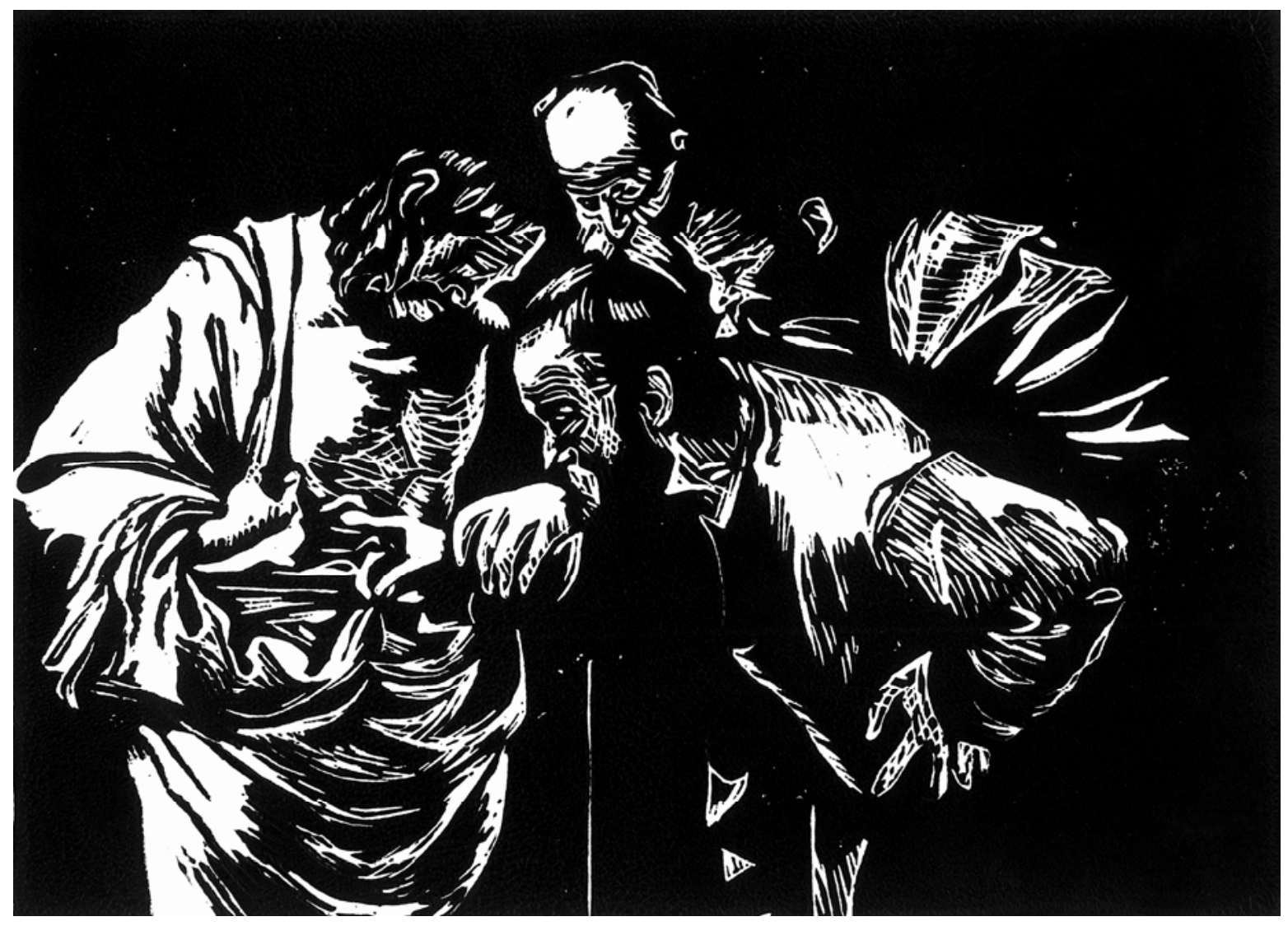

Already a devout Christian, the painting reflects a religiosity Chad had has never previously felt. It embodies the reality of faith in a way that the biblical story, when told, never could. And like the painting's very subject, it makes Chad believe. It is his faith incarnate.

Few images ever offer us literal conversions. More often, they merely represent them. Any motivations created by an image necessarily follow from our initial encounter. If we find their imagery pleasant, we may suggest that a friend look at it. Or if we are outraged by what we see, we might be spurred to act, demonstrate, or protest against its subject. There exists a space of contemplation between our seeing and acting upon most images. Rarely do they act as immediate agents of change; rarely does an image convert us by the simple fact of our seeing it. And yet, Chad seems profoundly affected by merely looking upon this painting.

In experiencing the sublimity of an image, we may be irrevocably changed by it. This change does not follow from our encounter with the image; it is immediately bound up in it. It may even arise in the very instant of the image-encounter. In the very moment he sees Doubting Thomas, Chad may recognize his faith as having been not quite given over, always hesitant, always doubting, until now when Christ is brought close. Following the root of the word convert, Chad is "turn[ed] around" and "transforme[d]" (convert, Online Etymological Dictionary, 2012) by the image. He is, quite simply, converted as thoroughly as any sinner who becomes a true believer. Indeed, Chad's seems a conversion in the most traditional sense of the word. And yet, to be converted implies that we are changed by the active presence of another being. Religious 
conversions can only occur in an encounter between two mutually interacting parties, whether human or divine.

To be converted by an image, then, necessitates that we entered into a different type of relationship with the image. We no longer stand before a picture and, through our knowledge and effort alone, discern its symbols and meaning. Rather, in its sublimity an image can take on a living quality, presenting itself as an independent subject to be addressed, addressing us in turn. We look upon it and it speaks back to us directly. In his study of Rilke's “Archaic Torso of Apollo,” Bernd Jager (2004) proposes that artworks take on this type of subjecthood when the viewer moves from the workday world, where s/he is oriented by instrumentality and scientific understanding, into the festive world, a world of reciprocity and intersubjective existence. Perhaps the image's sublimity speaks to Chad and affects him so deeply because it brings him into the festive realm and there, like Apollo's torso, demands he “alter [his] life” (p. 16) "by turning to an Other and thereby enter into a truer, deeper, more revealing relationship to his world” (p. 17). ${ }^{15}$ This 'truer, deeper, more revealing relationship to his world' may be, for Chad, that of a living faith. For what the image suggests is more than that the need to recognize the importance of the parable of doubting Thomas - that is evident to anyone familiar with the Christian story who looks upon the painting. What the image's sublimity conveys is more personal, more profound. It is an intimate conversation from which others are excluded and, in which, Chad may be revealed to himself. A sublime image may make visible to us who we are: doubters, lacking in some profound respect. We may have never before seen ourselves in this light, but once shown its truth may seem undeniable. At the same time, however, the sublime image does not simply damn us for our potential shortcomings, for doubting; it can also show us who we should and can be. Chad is reflected in Thomas both before and after Thomas' conversion. In that moment, Chad becomes both sinner and saved - he is both his past and future selves. To encounter the sublimity of image, therefore, can create a sense of an opening, a moment wherein we become aware of ourselves in time, as both no longer and not yet, who we were and who we will now become.

In the years since that first encounter, Chad keeps the image close to him. He owns a poster of it, downloads a digital copy, and uses the image regularly in his work as a youth pastor. He also travels Europe, visiting the greatest of cathedrals and best art galleries, but he says:

Nothing has ever recaptured the sensation I felt that first night in the simplest of student apartments.

For Chad, the sublime encounter with the image that night long ago brought him closer to God. So close that he now uses the image as a pedagogical tool in his pastoral work. And yet, that first experience, while powerful, seems incredibly fragile. Although he has searched out Caravaggio's other paintings, he admits to actively avoiding seeing Doubting Thomas. Chad says: I'm not sure if I ever want to see it. The possibility of seeing it in the flesh, so to speak, is terrifying. Would he, like Thomas, doubt the veracity of what he sees? Would its aura have been lost through its endless mechanical reproduction (Benjamin, 1968)? And if he saw this painting, would he need, once again, to have the sublime enter him, like Thomas' finger entering the wound of Christ, in order 
to believe? And what if the image did not, like Jesus, offer the demanded proof? Would he be revealed to have always doubted? To see this painting is to risk all of this and, at root, seems to risks Chad's faith. He admits:

I'm afraid I will be disappointed. Or maybe, I acknowledge that closeness and holiness are mutually excluding.

Chad's closing remarks touch upon a strange aspect of the sublime: that through familiarity, it can disappear. Upon repeated exposure to the sublime image-sometimes even simply seeing it twice-we may only end up with a mute picture in front of which we wonder: how could it ever have moved me so?

And yet, we pause again, for I wonder: are we drawing upon religious understanding because we are unable to articulate it in any other way? Can the 'conversion' we may experience because of the sublimity of an image be understood in a secular manner?

Consider Han's experience. He tells of how, on a trip outside Mainland China, he attends a candlelight vigil. Walking past a display, he sees an old photograph faded and yellowed showing a lone man facing military tanks - it is an image with which many of us are familiar, but which for Han is entirely new. ${ }^{16}$ He says:

As I look at that image, it calls into question everything I have been taught, everything I have believed about our ruling party. And I wonder: Is this the China that I know? Is this the China I want to live in?

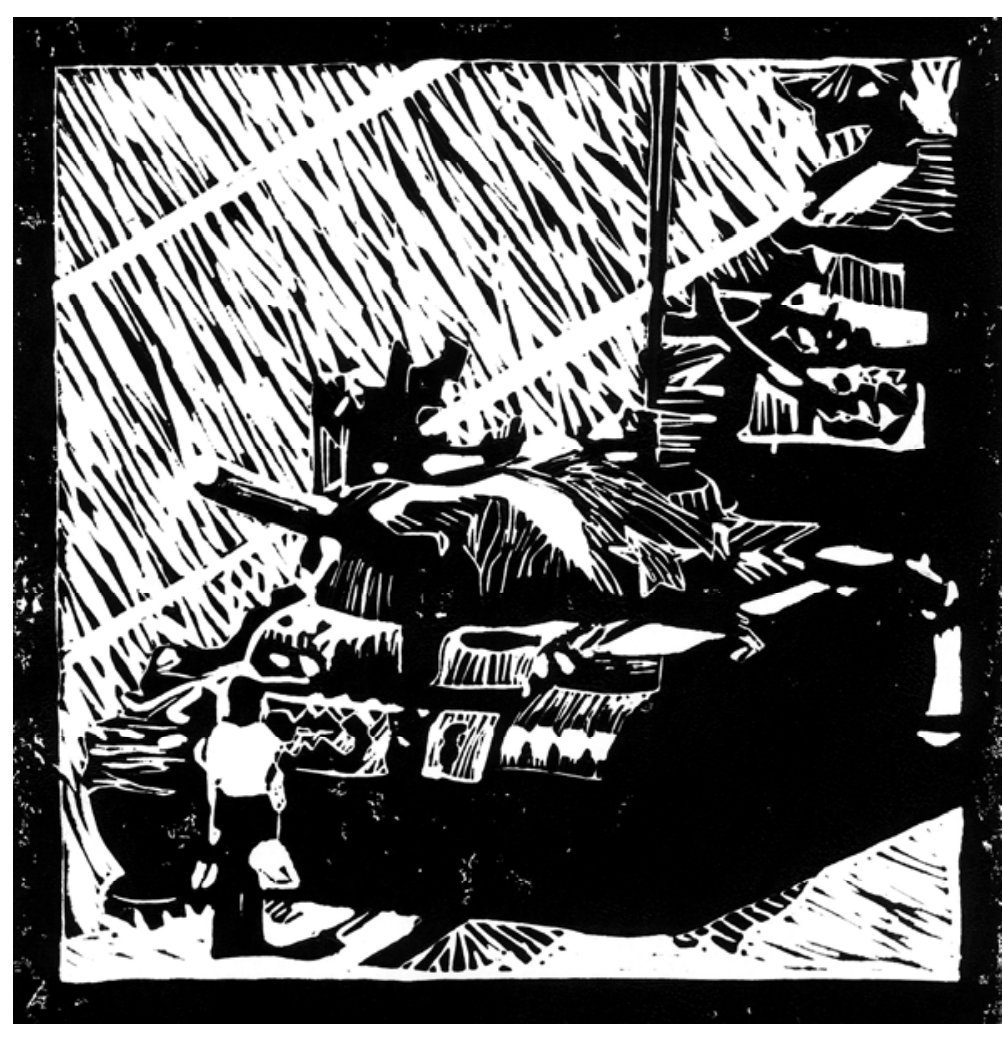

Confronted with the image of the lone man in Tiananmen Square, Han confronts the country in which he has lived but the reality of which he has never before realized. And what he sees is new and terrifying.

As David Morgan (2010) writes, in the face of the sublime "my world crumbles before the looming prospect of a reality that threatens to replace the foundations of the familiar" (p. 82). For Han, this 'looming prospect' is the realization of the violence and oppression perpetrated by the Chinese state, but the new reality that is suggested may not be so one-sided. Han 
continues:

As I stare at tank-man, the image seems to change. I see Tank-man's courage to confront authority despite his comparative weakness. And I see the mercy the first tank uniquely displays. And it gives me hope.

While the image he beholds destroys his familiar, comfortable world, Han is not left simply shattered. As Han continues to look at the image, what at first appears upsetting and horrifying begins to reveal within itself the grace of mercy and hope. It even shows him the awesomeness of how one man, small and frail, can confront and overcome a row of large military tanks through his simple humanity. Therefore, while the sublime may tear away the familiar, it can also be considered an offering. What seems offered to Han is a world that can potentially be changed, with him as a part of it. Although he will not see the image again, it and the hope it engenders will accompany him in the subsequent years. Han tells how:

In my mind, numerous Chinese fighters, such as Liu Xiaobo and Ai Weiwei have come to stand in the place of that unknown young man.

This image does not only change Han and his perception of his world, for Han, this image is change. To encounter the sublime through an image, then, can threaten to shatter our world, but it may also offer us the vision of a new and better one, one we had never considered or thought possible-regardless of whether we perceive our new sight to be of a divine cause or not.

\section{Caught Between World \& Image: A Sublime Awakening}

The sublime-this strange and curious thing has fascinated us for centuries. It is something universally understandable and yet so individual, so personal that we are only able to encounter it alone. It appears neither wholly a response to, nor a mere quality of the image we behold, but both at once. As it arises from our encounters with images, we can begin to perceive its contours, its capacities as a human experience. And what we find is that the sublime seemingly affects more than just the image that evokes it or even our perception of the world. A sublime encounter can 'bring us into the picture' more fully than any other experience, but also well beyond it. painting. ${ }^{17}$

Jean-Luc Marion (2002) describes standing in front of another Caravaggio 


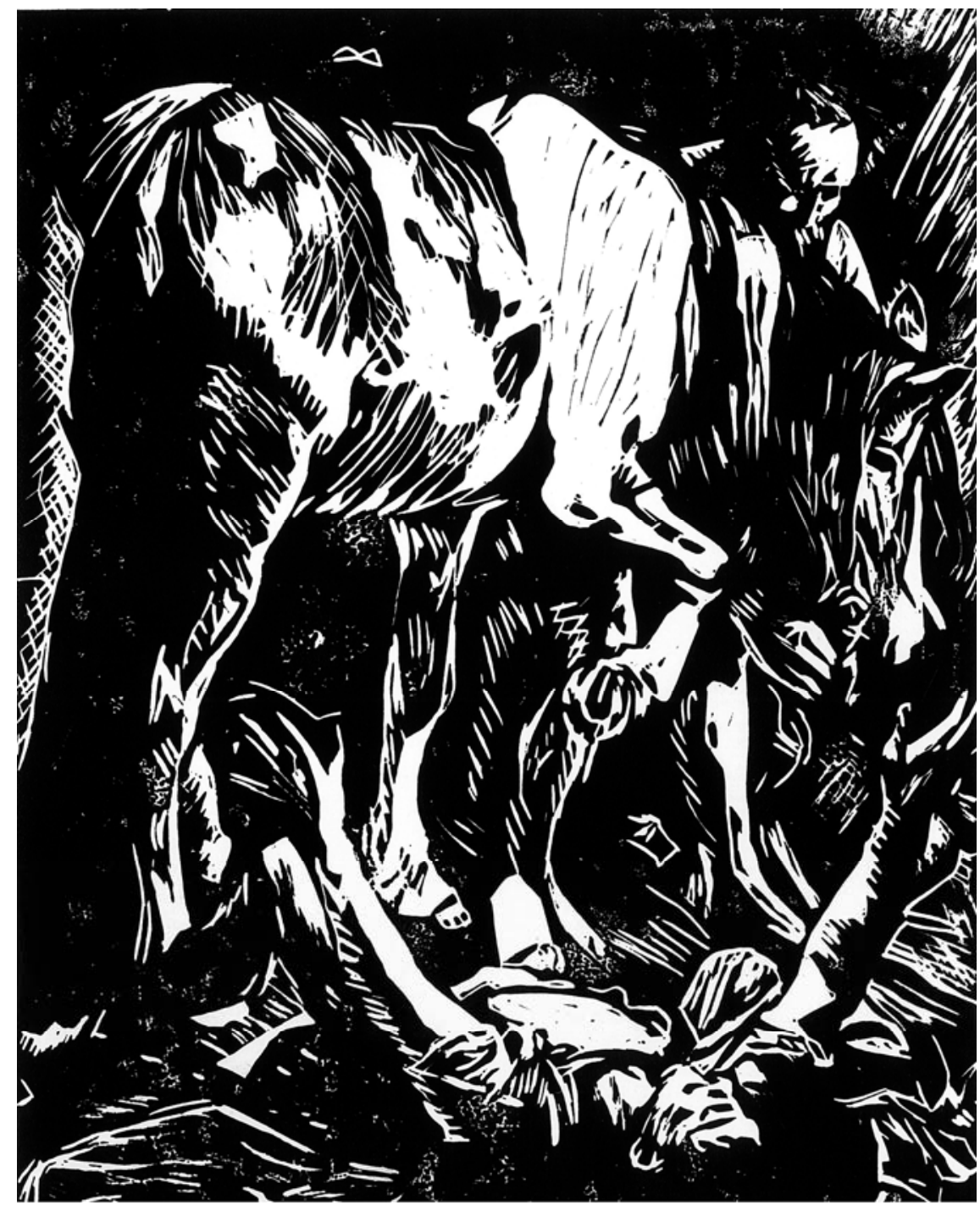

In front of The Conversion of Saint Paul, knocked down, lowered from his warlike posture of a horseman, or rather, paralyzed in free fall, eyes closed by an anonymous light that seems to come from the exterior of the painting and is reflected on the flesh of his horse, am not wondering about the largely hidden anatomy of the animal, or about the silhouette of the manservant, almost vanished, moreover in the shadow. I am not even inquiring about the identity of the light (or of the voice) that calls him: I am overwhelmed, the luminous lake flooding all at once the side opposed to the flash of lightning, which seems to have struck in front of the painting, thus behind my back. This is to the extent that I should even have the reflex to turn around, in order to understand what has happened in front of the painting. Here the visible does not only crush the painted spectacle but also encloses the spectator, seen by the light more than he or she sees it. (p. 64) 
Like the painting's light, the sublime may manifest most evidently upon the canvas, but the image does not seem its source. Rather, the sublime seems to come from our world, from something beyond us, which we feel we must turn to find in order to understand that which we see before us. To turn to look for the source of illumination is our intuitive response-and that may be the very cause of our centuries of philosophizing about the topic. Much like Marion's experience of the light, in our philosophy we see evidence of the sublime but cannot readily, concretely locate it. And this can be confusing. While we may rationally argue that the sublime must be within us, must be an aesthetic response to the image-object, the sublime always remains beyond our ken. For having seen how significantly it can alter an image, in our turning towards its apparent source, the sublime disappears.

Just as Marion is drawn into the light that illuminates and transforms St. Paul, we, too, may feel that we are enfolded within the sublime's radiance. As we stand in that radiance, we become caught between image and world. We move beyond the concerns of the image, beyond our own petty concerns, and even beyond the concerns of the everyday world. Facing the image, feeling its light and pull, the sublime's call and demand can become a fundamental need. While we may encounter the sublime through the image, the sublime does not remain there. It seemingly takes root in us. As Rudd Welten (2011) writes, when we experience the sublime, "nothing happens beyond us, but things happen inside, our outlook is transforming” (pp. 220-221). In encountering the sublime through an image, we may therefore become enclosed, illuminated, and influenced by it far more than we immediately perceive. It can ignite a change of being (Goble, 2008/2012), similar to the effect of Bachelard's (1964) poetic image that "possess[es] us entirely" and "through its exuberance, awaken[s] new depths..." (p. xviiixix) ${ }^{18}$ While the sublime may unsettle, upset, terrify, and even horrify, so too does it inspire, foster, enchant, and even compel our reconsideration. In this way, to encounter the sublime may be to be brought, like St. Paul, to our own conversion-not a religious kind, but a more fundamental, existential one: an awakening towards something new, something beyond us, perhaps even wholly other, but of which we cannot deny that we are a part.

\section{References}

Abramovic, M. (1992, 2010). Statements. In S. Morley’s (Ed.) The sublime (p. 212). London \& Cambridge, MA: The MIT Press.

Aretoulakis, E. (2008). Aesthetic appreciation, ethics, and 9/11. Contemporary Aesthetics, 6(1). Retrieved from http://www.contempaesthetics.org/newvolume/pages/article.php?articleID=510

Bachelard, G. (1964). The poetics of space (M. Jolas, translator). New York: Orion Press.

Bachelard, G. (1961, 2012). The flame of a candle (J. Caldwell, translator). Dallas, TX: The Dallas Institute Publications. 
Barthes, R. (1981). Camera lucida: Reflections on photography. New York: Hill \& Wang.

Bataille, G. (1949, 2003). The Cruel Practice of Art. Originally published in Médicine de France June 1949. Translated and reprinted in BLAM!, 1993, digitized 2003. Retrieved from http://www.sauer-thompson.com/essays/BatailleCruel Practice.pdf

Benjamin, W. (1968). Illuminations: Essays and reflections. New York: Schocken Books.

Berleant, A. (2010). Sensibility and sense: The aesthetic transformation of the human world. Exeter, UK: Imprint Academic.

Brunius, T. (1970). The aesthetics of Roman Ingarden. Philosophy and Phenomenological Research, 30(4), 590-595.

Burke, E. (1757, 1958, 2008). A philosophical enquiry into the sublime and beautiful. New York, NY: Routledge and Keagen Paul.

Calvino, I. (2009). Six memos for the next millennium: The Charles Eliot Norton Lectures (1985-86) (P. Creagh, translator). London: Penguin Group.

Casey, E.S. (2007). The world at a glance. Bloomington, IN: Indiana University Press.

Chignell, A., \& Halteman, M.C. (2012). Religion \& the sublime. In T. Costelloe’s (Ed.) The sublime: From antiquity to the present (pp. 183-202). New York: Cambridge University Press.

Costelloe, T. (2012). A short introduction to a long history. In T. Costelloe's (Ed.) The sublime: From antiquity to the present (pp. 1-7). New York: Cambridge University Press.

Derrida, J. (1987). The truth in painting. (G. Bennington \& I. McLeod, trans.). Chicago \& London: University of Chicago Press

Dufrenne, M. (1973). The phenomenology of aesthetic experience. (E.S. Casey, A.A. Anderson, W. Domingo, \& L. Jacobson, trans.). Evanston, IL: Northwestern University Press.

Elliot Stone, B. (2006). Curiosity as the Thief of Wonder: An Essay on Heidegger's Critique of the Ordinary Conception of Time. Kronoscope, 6(2): 205-229.

Goble, E. (2008/2012). The experience of encountering the sublime. Phenomenology Online. Retrieved from http://www.phenomenologyonline.com/sources/ textorium/goble-erika-the-experience-of-encountering-the-sublime/ 
106 Goble

Gracyk, T. (2012). The sublime and the fine arts. In T. Costelloe's (Ed.) The sublime: From antiquity to the present (pp. 217-229). New York: Cambridge University Press.

Harbison, R. (1991, 2001). The Built, the Unbuilt, and the Unbuidable: In Pursuit of Architectural Meaning. Cambridge, MA: the MIT Press.

Hariman, R. and Lucaites, J.L. (2003). Public identity and collective memory in U.S. iconic photography: The impact of “Accidental Napalm.” Critical Studies in Media Communication, 20(1), 35-55.

Hegel, G.W.F. (1835/ 1975). Aesthetics: Lectures on fine arts. (T.M. Knox, trans). Oxford: Claredon Press.

Hepburn, R.W. (1984). 'Wonder' and Other Essays: Eight Studies in Aesthetics and Neighbouring Fields. Edinburgh: Edinburgh University Press.

Herbert, L.M. (1998, 2010). Spirit and light and the immensity within. In S. Morley’s (Ed.) The sublime (pp. 96-102). London \& Cambridge, MA: The MIT Press.

Hove, P. (2012). Pedagogy in the Face of Wonder. Phenomenology Online. Retrieved from http://www.phenomenologyonline.com/sources/textorium/hove-philopedagogy-in-the-face-of-wonder/

Hutchings, P. (2002). 11 September and the 's[sublime]' word. Sophia, 41(1), 71-72.

Ingarden, R. (1985). Aesthetic experience and aesthetic objects. Selected Papers in Aesthetics. Munchen: Philosophia Verlag.

Jager, B. (2004). Rilke’s “Archaic Torso of Apollo.” Journal of Phenomenological Psychology, 34(1): 79-98.

Johnson, D.B. (2012). The postmodern sublime: Presentation and its limits. In T. Costelloe's (Ed.) The sublime: From antiquity to the present (pp. 118-131). New York: Cambridge University Press.

Kant, I. (1793, 2000, 2007). Critique of the power of judgment (P. Guyer, editor, P. Guyer \& E. Matthews, translators). New York, NY: Cambridge University Press.

Kirwan, J. (2005). Sublimity: The non-rational and the rational in the history of Aesthetics. New York: Routledge.

Lacan, J. (1986, 1992). The seminars of Jacques Lacan, Vol. VII. (D. Porter, trans.). New York, NY: W.W. Norton.

Leier, B. (2012). The “problem” of compassion. Health Ethics Today, 20(1), 7-12. 
Levinas, E. (2006). Humanism of the Other. (N. Poller, Trans.). Chicago: University of Illinois Press.

Longinus (1971). On the Sublime. In H. Adams' (ed.) Critical theory since Plato, (pp. 77-102). San Diego, CA: Harcourt Brace Jovanovich, Inc.

Lyotard, J.F. (1979, 1984). The postmodern condition: A report on knowledge. (G. Bennington \& B. Massumi, trans.). Minneapolis: The University of Minnesota Press.

Marion, J.L. (2002). In excess: Studies in saturated phenomena. (R. Horner \& V. Berraud, trans.). New York, NY: Fordham University Press.

Merleau-Ponty, M. (1964). The Primacy of Perception And Other Essays on Phenomenological Psychology, the Philosophy of Art, History and Politics. (James M. Edie, translator). Evanston, IL: Northwestern University Press.

Morgan, D. (2009). Enchantment, disenchantment, re-enchantment. In J. Elkins’ \& D. Morgan’s (Eds). Re-Enchantment (pp. 3-22). New York: Routledge.

Morgan, D. (2010). Secret wisdom and self-effacement: The spiritual in the modern age, 1996. In S. Morley’s (Ed.) The sublime, (pp. 82-85). London \& Cambridge, MA: the MIT Press.

Nancy, J.L. (1993). The sublime offering. In J.F. Courtine, M. Deguy, E. Escoubas, P. Lacoue-Labarthe, J.F. Lyotard, L. Marin, J.L. Nancy, \& J. Rogozinski’s On the sublime: Presence in question. (J.S. Librett, trans.) (pp. 25-54). Albany, NY: State University of New York.

Newman, B. (1948/2003). The sublime is now. In C. Harrison \& P. Wood's Art in theory:1900-2000, An anthology of changing ideas. (pp.580-582). Oxford, Malden, \& Victoria: Blackwell Publishing Inc.

Online Etymological Dictionary (2012). Online etymological dictionary. (D. Harper, ed.). Retrieved from http://www.etymonline.com/

Oxford English Dictionary Online. (March 2013). Oxford English Dictionary ( $3^{\text {rd }}$ edition) (J. Simpson, ed.). Oxford: Oxford University Press. Retrieved from http://www.oed.com

Otto, R. (1958). The idea of the holy. New York, NY: Galaxy Books \& Oxford University Press.

Potkay, A. (2012). The British romantic sublime. In T. Costelloe's (Ed.) The sublime: From antiquity to the present (pp. 203-216). New York: Cambridge University Press. 
108 Goble

Purcell, L.S., (2010). Phenomenology of a photograph, Or: how to use an eidetic phenomenology. PhaenEx 5(1), 12-40.

Reynolds, F. (1785, 1996). An enquiry concerning the principles of taste. In A. Ashfield \& P. de Bolla's (eds.) The sublime: A reader in British eighteenth-century aesthetic theory. (pp. 124-126). Cambridge, UK: Cambridge University Press.

Schelling, F.W.J. (1859, 1989). The philosophy of art (Douglas W. Stott, translator). Minneapolis: University of Minnesota Press.

Schelling, F.W.J. (1800, 1978). System of transcendental idealism (Peter Heath, trans.). Charlottesville: University Press of Virginia.

Schopenhauer, A. (1819, 1958). The world as will and representation (E.F.J. Payne, translator). Indian Hills, Colorado: The Falcon’s Wing Press.

Shaw, P. (2007/2010) Lacan: Sublimity and Sublimation. In S. Morley’s (Ed.) The sublime, (pp. 52-55). London \& Cambridge, MA: the MIT Press.

Shaw, P. (2006). The sublime. New York, NY: Routledge.

Sircello, G. (1993). How is a theory of the sublime possible? The Journal of Aesthetic and Art Criticism, 51(4), 541-550.

Sobrino, J.. (1992). Compassion: The shaping principle of the human and of the Christian. The Nash Lecture (Campion College).

Sontag, S. (2003). Regarding the pain of others. New York: Picador.

Taylor, B. (2003). “Our bruised arms hung up as monuments”: Nuclear iconography in post-Cold Ward culture. Critical Studies in Media Communication, 20(1), 1-34.

Van den Berg, J.H. (1972). A different existence: Principles of phenomenological psychopathology. Pittsburgh, PA: Duquesne University Press.

Van Manen, M. (1997). Researching lived Experience: Human science for an action sensitive pedagogy. London, ON: The Alhouse Press.

Van Manen, M. (2012). Phenomenology Online. Available at www.phenomenologyonline.com.

Waldenfels, B. (2011). Phenomenology of the alien: Basic concepts (Alexander Kozin \& Tanja Stahler, translators). Evanston, IL: Northwestern University Press.

Welten, R. (2011). Melville’s 'Sublime Uneventfulness'. Toward a phenomenology of the sublime. In D. Loose's (Ed.) The sublime and its teleology: Kant - German Idealism - Phenomenology (pp. 205-222). Lieden, The Netherlands: Brill.

Žižek, S. (1989). The sublime object of ideology. London \& New York: Verso. 


\begin{abstract}
${ }^{1}$ Patrick Hutchings (2002) observes how, at first, the term 'sublime' seemed offensive to apply to the September $11^{\text {th }}, 2001$ attacks and chastises the media for applying the term mere months later. However, he concludes that such an application calls for a renegotiation of the Kantian sublime. This renegotiation was first broached by Emmanouil Aretoulakis (2008), who explored the aesthetic aspects of the attacks through the Kantian understanding of the beautiful and the sublime, but it was fully articulated as sublime by Arnolt Berleant (2010) who reconceived the sublimity of the attacks as a 'negative aesthetic.'
\end{abstract}

${ }^{2}$ This is not limited to the English language. In French, the term, sublime, is similarly used to refer to the very pleasing of the everyday life; as in "c'est crème glaçée est sublime!" which translates to, "this ice cream is sublime."

${ }^{3}$ The study was funded by the Social Sciences and Humanities Research Council of Canada and the Killam Trust. The project received ethical approval for the University of Alberta's Research Ethics Board 1. Please note that this article presents only selected pieces of a much larger study.

I would like to thank my doctoral supervisors, Drs. Catherine Adams and Max van Manen, for their ongoing support feedback. I would also like to thank the member of the phenomenology support group, Iris Yin, Nicole Glenn, Kathy Howery, and Peggy Jubien.

${ }^{4}$ The specific reflective methods used during the course of this study included the thematic analysis, exploration of the language participants used (including the definitions and etymologies of key words), existential reflections, and eidetic reductions (see van Manen 1997 and 2012 for a full description of these methods). Each of these may be more or less apparent in this text.

${ }^{5}$ Nine persons were interviewed and/ or provided a written account of their experience. This was in addition to four other accounts that had been collected as part of a pilot study in 2008. While all accounts have been used in the larger study, only those relevant to the sections here are presented.

${ }^{6}$ My decision to transform the images into linocuts was based on the desire to create a unification of the overall text. Moreover, changing the images' form was a means to generate a sense of closeness and recognition of the experience of the image while simultaneously creating a reflective distance. In this way, it can be considered similar to phenomenological writing itself. Should readers wish to see the original images, links to digital reproductions of the works have been provided.

${ }^{7}$ To see the original image, go to https://www.adbusters.org/cultureshop/backissues/94

${ }^{8}$ Exploring this paradox was a core feature of my first exploration of the sublime (see: Goble, 2008/2012).

${ }^{9}$ To see the original image, go to http://www.africansuccess.org/visuFiche.php?lang=en\&id=1029 
${ }^{10}$ One need only look at the 'comments section' of websites that post the photograph to see that, even 10 years after the image's first publication, public responses of outrage towards Carter for taking the photograph persist. Carter, too, questioned his actions as a war photographer and was affected by many of the images he had created. He committed suicide in 1994. Although Carter's photographs cannot be held solely responsible for his suicide, the horror of having to live with what he had seen and photographed was listed amongst other extenuating factors in his suicide note.

${ }^{11}$ To see the original image, go to http://www.saatchi-gallery.co.uk/artists/artpages/zhang_huan_seeds.htm

${ }^{12}$ Susan Sontag made this observation (2003). Bataille, however, points out that the expression might also be due to the effect of opium that he believes was administered.

${ }^{13}$ Lacan was the first to connect the sublime and sublimation in psychoanalysis.

${ }^{14}$ To see the original image, go to http://en.wikipedia.org/wiki/File:Caravaggio__The_Incredulity_of_Saint_Thomas.jpg

${ }^{15}$ Jager (2004) writes, "The most fundamental change that can occur in the human world comes about as a result of the festive meeting of self and other. It is this meeting that lays the foundation of a human and a divine world" (p. 17).

${ }^{16}$ To see the original image, go to http://en.wikipedia.org/wiki/File:Tianasquare.jpg.

${ }^{17}$ Marion refers to this painting as The Conversion of Saint Paul. It is, however, properly titled Conversion on the Way to Damascus. To see the original image, go to http://en.wikipedia.org/wiki/File:Conversion_on_the_Way_to_DamascusCaravaggio_\%28c.1600-1\%29.jpg.

${ }^{18}$ We might even wonder if this is what Bachelard was referring to when he wrote his introduction to The Poetics of Space. 